\title{
Orphan Drugs Offer Larger Health Gains but Less Favorable Cost-effectiveness than Non-orphan Drugs
}

\author{
James D. Chambers, PhD, Madison C. Silver, BA, Flora C. Berklein, MPH, \\ Joshua T. Cohen, PhD, and Peter J. Neumann, ScD
}

Center for the Evaluation of Value and Risk in Health, Institute for Clinical Research and Health Policy Studies, Tufts Medical Center, Boston, MA, USA.

\begin{abstract}
BACKGROUND: Orphan drugs offer important therapeutic options to patients suffering from rare conditions, but are typically considerably more expensive than nonorphan drugs, leading to questions about their costeffectiveness.
\end{abstract}

OBJECTIVE: To compare the value of orphan and nonorphan drugs approved by the FDA from 1999 through 2015.

DESIGN: We searched the PubMed database to identify estimates of incremental health gains (measured in quality-adjusted life-years, or GALYs) and incremental costs that were associated with orphan and non-orphan drugs compared with preexisting care. We excluded pharmaceutical industry-funded studies from the dataset. When a drug was approved for multiple indications, we considered each drug-indication pair separately. We then compared incremental BALY gains, incremental costs, and incremental cost-effectiveness ratios for orphan and non-orphan drugs using the Mann-Whitney $U$ (MWU) test (to compare median values of the different distributions) and the Kolmogorov-Smirnov (KS) test (to compare the shape of different distributions).

RESULTS: We identified estimates for 49 orphan drugindication pairs, and for 169 non-orphan drug-indication pairs. We found that orphan drug-indication pairs offered larger median incremental health gains than non-orphan drug-indication pairs (0.25 vs. 0.05 QALYs; MWU $p=$ 0.0093 , KS $p=0.02$ ), but were associated with substantially higher costs $(\$ 47,652$ vs. $\$ 2870 ;$ MWU $p<0.001$, KS $p<0.001)$ and less favorable cost-effectiveness $(\$ 276,288$ vs. $\$ 100,360$ per QALY gained; MWU $p=0.0068$, KS $p=$ 0.009).

CONCLUSIONS: Our study suggests that orphan drugs often offer larger health gains than non-orphan drugs, but due to their substantially higher costs they tend to be less cost-effective than non-orphan drugs. Our findings highlight the challenge faced by health care payers to provide patients appropriate access to orphan drugs while achieving value from drug spending.

KEY WORDS: cost-effectiveness; orphan drugs; rare disease; access; managed care.

Electronic supplementary material The online version of this article (https://doi.org/10.1007/s11606-020-05805-2) contains supplementary material, which is available to authorized users.

Received November 25, 2019

Accepted March 12, 2020

Published online April 13, 2020
J Gen Intern Med 35(9):2629-36

DOI: $10.1007 / \mathrm{s} 11606-020-05805-2$

(c) Society of General Internal Medicine 2020

\section{INTRODUCTION}

Since 2015, almost half of the drugs approved by the FDA have been orphan drugs, defined as drugs indicated for diseases affecting fewer than 200,000 patients in the USA, and this proportion has increased over each of the past three decades. ${ }^{1,2}$ Rare diseases are often inherited disorders and severe in nature, and affect very young, vulnerable populations. Examples of inherited rare diseases include cystic fibrosis, spinal muscular atrophy, Duchenne muscular dystrophy, and Fabry disease. Orphan drugs have provided important therapeutic options for many of these conditions, for which few, if any, prior treatments were available. For instance, in 2019, the FDA approved pexidartinib for symptomatic tenosynovial giant cell tumor, and caplacizumab-yhdp for acquired thrombotic thrombocytopenic purpura (a lifethreatening disorder that causes blood clotting); these drugs were the first therapies approved for these conditions. ${ }^{3,4}$

Orphan drugs have attracted attention because they cost roughly five times more than non-orphan drugs $(\$ 150,854$ vs. $\$ 33,654$ per year). ${ }^{5,}{ }^{6}$ Orphan drug spending in the USA increased from 4\% of total prescription drug spending in 1997 to $10 \%$ in 2017 . In 2017 , spending on orphan drugs in the USA reached $\$ 43$ billion, ${ }^{7}$ raising questions about whether the costs are worth the drugs' clinical benefits. Researchers examining out-of-pocket spending on orphan drug prescriptions among commercially insured adults in the USA found that the mean spending per patient in 2014 was $\$ 333 .{ }^{8}$

We estimated incremental health gains, incremental costs, and cost-effectiveness associated with orphan drugs upon their FDA approval, relative to prevailing treatment options-i.e., existing drug or nondrug treatments.

\section{METHODS}

We analyzed a database of estimates of incremental health gains and incremental costs associated with FDA-approved drugs approved from 1999 through 2015. This database has been used previously to compare the value of specialty and 
traditional drugs, and to examine whether drugs included in the FDA's expedited approval programs offer larger health gains than drugs approved through standard processes. ${ }^{9}, 10$ The database reports health gains as incremental qualityadjusted life-years (QALYs), associated with a new drug compared with prevailing treatment options at the time of drug approval. QALYs characterize health gains by combining longevity and quality of life into a single metric, thus facilitating comparison of treatment effects across diseases. ${ }^{11}$ Costs are reported as the incremental costs associated with use of a new drug compared with prevailing treatment options at the time the drug was approved, and account for all drug and other treatment-related costs (for example, associated hospitalization costs and potential cost offsets).

The database used for this analysis has been described in detail elsewhere. ${ }^{9},{ }^{10}$ Briefly, we first searched the FDA's website to identify all new molecular entities approved from 1999 through $2015 .{ }^{12}$ Second, to identify incremental QALY gains and incremental cost estimates, we searched PubMed for published cost-per-QALY studies, and for published comparative-effectiveness studies that reported effectiveness using QALYs, but do not report incremental costs. We searched for the drug's chemical and brand names and for the terms quality adjusted life year OR QALY. We limited our search to studies published in English-language journals and involving human participants. Third, we reviewed each identified study to ensure it met the following inclusion criteria:

1. Included a drug approved by the FDA from 1999 through 2015;

2. Compared the drug with a treatment available at the time of the drug's approval;

3. Compared the drug with an active treatment, or best supportive care if no treatment was available (we excluded studies that included placebo or no treatment as the comparator).

To be conservative, we excluded pharmaceutical industryfunded studies from the dataset, as industry-funded cost-effectiveness analyses tend to report more favorable findings. ${ }^{13,14}$

Fourth, we extracted estimates of incremental QALYs and costs from the included studies. When a study compared a drug with multiple alternatives, we included the estimate comparing the drug of interest with the most effective alternative available at the time of the drug's approval. For example, one study compared adalimumab (approved for Crohn's disease in 2007) with three alternatives: infliximab (approved in 1998), certolizumab pegol (approved in 2008), and natalizumab (approved in 2008). ${ }^{15}$ Only infliximab received FDA approval for Crohn's disease before adalimumab and hence, served as the comparator therapy for subsequently approved adalimumab. We included base case estimates for incremental QALYs and cost, averaging values when a study reported multiple base case estimates. When multiple studies provided estimates for a single drug, we averaged these estimates.

Fifth, we determined whether the FDA granted the drug orphan status. ${ }^{16}$ Because orphan designation is indicationspecific, we organized the dataset using the drug-indication pair as the unit of analysis. For example, pembrolizumab is approved for unresectable or metastatic melanoma (an orphan indication) and non-small cell lung cancer (a non-orphan indication). Thus, we included separate incremental QALY and incremental cost estimates for unresectable or metastatic melanoma and non-small cell lung cancer.

Sixth, for non-US studies, we converted cost to US dollars using the foreign exchange rates obtained from the US Federal Reserve Website. ${ }^{17}$ We then inflated all cost estimates to 2018 values using the US consumer price index. ${ }^{18}$

\section{ANALYSIS}

For each drug-indication pair, we estimated a costeffectiveness ratio by dividing incremental cost by incremental QALY gains. We then compared incremental QALY gains, incremental costs, and incremental cost-effectiveness for orphan and non-orphan drugs using the Mann-Whitney $U$ test (to compare the orphan and non-orphan medians sets) and the Kolmogorov-Smirnov test (to compare the orphan and nonorphan distributions). We used these non-parametric tests because the data sets exhibited substantial skew. Sensitivity analyses repeated these comparisons, including (1) only the highest and then (2) only the lowest incremental QALY gain and cost estimates. We designated results with $p$ values below $5 \%$ to be statistically significant.

We compared studies conducted on orphan drugs and nonorphan drugs using the following criteria: approval year, country setting (US vs. non-US), study's price year, cancer vs. non-cancer, and study time horizon.

\section{RESULTS}

The FDA approved 494 new molecular entities (NMEs) from 1999 through 2015, of which 145 (29\%) were approved for at least one orphan disease. Twenty-eight drugs in our dataset featured multiple indications, meaning that we identified a qualifying cost-effectiveness study for more than one of the drug's FDA-approved indications. We identified at least one relevant comparative-effectiveness or cost-utility study for 172 drugs (35\%), of which 47 were approved for at least one orphan disease (comparative-effectiveness and cost-utility studies both report incremental health gains using QALYs; cost-utility studies additionally report incremental cost data, comparative-effectiveness do not). Accounting for drugs with multiple indications, we identified at least one relevant comparative-effectiveness or cost-utility study for 218 drugindication pairs, of which 169 were for non-orphan indications, and 49 were for orphan indications. Our dataset included 
365 cost-utility analyses, and 11 comparative-effectiveness studies (Appendix Table 1). Eighty-one drug-indication pairs were associated with a single study. We did not find systematic differences between studies conducted on orphan and nonorphan drugs, with the exception of whether drugs were indicated to treat cancer (57\% for orphan drugs vs. $18 \%$ for nonorphan drugs) (Appendix Table 2).

\section{Incremental QALY Gains}

Health gains across all drug-indication pairs averaged 0.38 QALYs (standard deviation 2.1), or roughly 20 weeks of

Table 1 Comparison of orphan and non-orphan drugs in terms of incremental costs, QALYs, and cost-effectiveness

\begin{tabular}{|c|c|c|c|}
\hline & All drugs & $\begin{array}{l}\text { Orphan } \\
\text { drugs }\end{array}$ & $\begin{array}{l}\text { Non- } \\
\text { orphan } \\
\text { drugs }\end{array}$ \\
\hline Number & 218 & 49 & 169 \\
\hline $\begin{array}{l}\text { QALY gain compared } \\
\text { with previous treatment } \\
\text { options }\end{array}$ & & & \\
\hline Median (IQR) & $0.09(0.38)$ & $0.25(0.69)$ & $0.05(0.31)$ \\
\hline Mean (SD) & $0.38(2.1)$ & $1.06(4.3)$ & $0.18(0.51)$ \\
\hline \multicolumn{4}{|l|}{ Additional costs $(\$)$} \\
\hline Median (IQR) & $\begin{array}{l}6085 \\
(40,655)\end{array}$ & $\begin{array}{l}47,652 \\
(155,065)\end{array}$ & $\begin{array}{l}2871 \\
(17,742)\end{array}$ \\
\hline Mean (SD) & $\begin{array}{l}135,302 \\
(963,920)\end{array}$ & $\begin{array}{l}529,524 \\
(1,990,171)\end{array}$ & $\begin{array}{l}21,002 \\
(100,099)\end{array}$ \\
\hline \multicolumn{4}{|l|}{$\begin{array}{l}\text { Aggregate incremental } \\
\text { cost-effectiveness ratios }\end{array}$} \\
\hline $\begin{array}{l}\text { Dominant (more } \\
\text { effective and less costly) }\end{array}$ & 22 & 2 & 20 \\
\hline Less than $\$ 25,000$ & 27 & 2 & 25 \\
\hline$\$ 25,000$ to $<\$ 50,000$ & 15 & 3 & 12 \\
\hline$\$ 50,000$ to $<\$ 100,000$ & 20 & 5 & 15 \\
\hline$\$ 100,000$ to & 16 & 3 & 13 \\
\hline$<\$ 150,000$ & & & \\
\hline$\$ 150,000$ to & 11 & 4 & 7 \\
\hline$<\$ 200,000$ & & & \\
\hline $\begin{array}{r}\$ 200,000 \text { to } \\
<\$ 250,000\end{array}$ & 10 & 3 & 7 \\
\hline$\$ 250,000$ to & 4 & 3 & 1 \\
\hline$<\$ 300,000$ & & & \\
\hline$\$ 300,000$ or more & 32 & 12 & 20 \\
\hline Dominated (less & 34 & 9 & 25 \\
\hline $\begin{array}{l}\text { effective and more } \\
\text { costly) }\end{array}$ & & & \\
\hline $\begin{array}{l}\text { Less costly and less } \\
\text { effective }\end{array}$ & 27 & 3 & 24 \\
\hline Disease category & & & \\
\hline Cancer & 62 & 26 & 36 \\
\hline Circulatory disease & 27 & 6 & 21 \\
\hline Endocrine disorders & 25 & 9 & 16 \\
\hline Infectious disease & 21 & 0 & 21 \\
\hline Musculoskeletal and & 21 & 3 & 18 \\
\hline rheumatologic disease & & & \\
\hline Diseases of the & 16 & 0 & 16 \\
\hline nervous system & & & \\
\hline Skin and subcutaneous & 11 & 0 & 11 \\
\hline tissue disease & & & \\
\hline Digestive disease & 8 & 0 & 8 \\
\hline $\begin{array}{l}\text { Mental and behavioral } \\
\text { disorders }\end{array}$ & 6 & 1 & 5 \\
\hline $\begin{array}{l}\text { Respiratory system } \\
\text { disease }\end{array}$ & 6 & 0 & 6 \\
\hline Eye conditions & 4 & 0 & 4 \\
\hline Genito-urinary disease & 4 & 1 & 3 \\
\hline Hematologic disease & 2 & 1 & 1 \\
\hline Other & 5 & 2 & 3 \\
\hline
\end{tabular}

quality-adjusted survival (Table 1). The median health gain was 0.09 QALYs (interquartile range 0.38). Orphan and nonorphan drug-indication pairs had median health gains of 0.25 (IQR 0.69) and 0.05 (IQR 0.31) QALYs respectively (MannWhitney $U$ test, $p=0.0093$; Kolmogorov-Smirnov test, $p=$ $0.02)$. Sixty-four drug-indication pairs in our dataset had zero health gains or were less effective than existing care (Fig. 1). Zero or fewer QALYs was also the case for 12 orphan drugindication pairs, and 52 non-orphan drug-indication pairs. Seven of the top ten drug-indication pairs with the largest QALY gains were orphan drugs (Table 2).

\section{Incremental Costs}

The mean and median incremental cost across all drug-indication pairs were \$135,302 (SD \$963,920) and \$6085 (IQR \$40,655), respectively (Table 1). Orphan and non-orphan drug-indication pairs had median incremental costs of $\$ 47,652$ (IQR $\$ 155,065$ ) and $\$ 2870$ (IQR $\$ 17,742$ ) respectively (Mann-Whitney $U$ test, $p<0.001$; Kolmogorov-Smirnov test, $p<0.001)$. Forty-nine drugs cost the same or less than existing care (Fig. 2). This was the case for 5 orphan drug-indication pairs and 44 non-orphan drug-indication pairs. Eight of the top ten drug-indication pairs with the largest incremental costs were orphan drugs (Table 3).

\section{Incremental Cost-effectiveness}

Two orphan drug-indication pairs and 20 non-orphan drugindication pairs were more effective and less costly than the comparator (Table 1). Nine orphan drug-indication pairs and 25 non-orphan drug-indication pairs were less effective and more costly than the comparator. The cost-effectiveness distributions for orphan and non-orphan drug-indication pairs differed (see online Appendix Figure 1). The costeffectiveness ratio was at least $\$ 150,000$ per QALY for $45 \%$ of the orphan drug-indication pairs and for $21 \%$ of non-orphan drug-indication pairs. Cost-effectiveness ratios for orphan drug-indication pairs tended to be less favorable (median of $\$ 276,288$ per QALY, IQR \$900,564) than cost-effectiveness for non-orphan drug-indication pairs $(\$ 100,360$ per QALY, IQR \$197,701) (Mann-Whitney $U$ test, $p=0.0068$; Kolmogorov-Smirnov test, $p=0.009) .{ }^{19}$

Sensitivity analyses exploring the impact of including only the highest QALY gain and cost estimates and then only the lowest QALY gain and cost estimates yielded results qualitatively similar to base case results described above, with the sign and order of magnitude, and significance unchanged (see online Appendix Table 3 and Table 4).

\section{DISCUSSION}

We found that orphan drugs tend to be associated with larger health gains than non-orphan drugs. Potential reasons for this finding include the severe nature of many rare diseases (and thus the potential for large health improvements) and the fact 


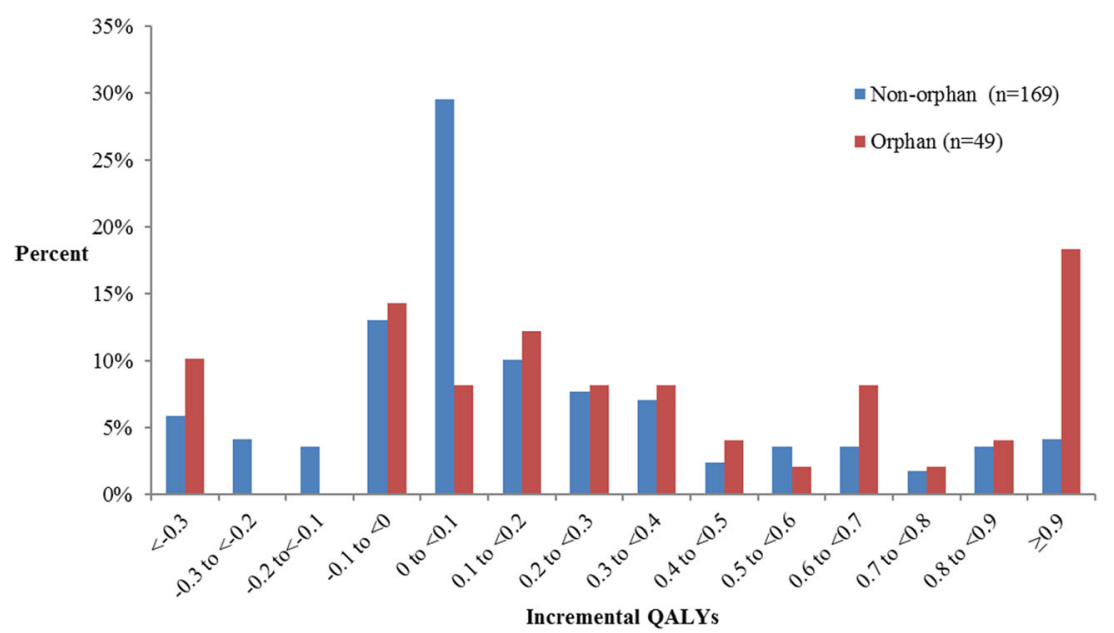

Figure 1 Distribution of incremental QALYs across orphan and non-orphan drugs. Source: Authors' analysis.

that orphan drugs are often approved for diseases for which few, if any, alternative therapies are available. However, our analyses show that despite larger health benefits, orphan drugs tend to be less cost-effective than non-orphan drugs.

That orphan drugs are often less cost-effective than nonorphan drugs is not surprising. Health technology assessment agencies often have separate processes and use higher (less favorable) cost-effectiveness thresholds when evaluating orphan drugs. An example is the modified value framework used by the Institute of Clinical and Economic Review in the USA from 2017-2019 which automatically designated drugs with cost-effectiveness ratios exceeding $\$ 175,000$ per QALY as "low value" but which allowed a committee to vote on value for drugs for ultra-rare diseases (affecting fewer than

Table 2 Fifteen drugs with the largest incremental quality-adjusted life-year (QALY) gains over preexisting care

\begin{tabular}{|c|c|c|c|c|c|c|}
\hline $\begin{array}{l}\text { Chemical name } \\
\text { (brand name) }\end{array}$ & Indication & $\begin{array}{l}\text { Orphan } \\
\text { designation? }\end{array}$ & $\begin{array}{l}\text { Year of } \\
\text { FDA } \\
\text { approval }\end{array}$ & $\begin{array}{l}\text { Average } \\
\text { incremental } \\
\text { QALY gain }\end{array}$ & $\begin{array}{l}\text { Average incremental } \\
\text { cost over the time } \\
\text { period used in the } \\
\text { reviewed cost-utility } \\
\text { study (\$) }\end{array}$ & $\begin{array}{l}\text { Aggregate } \\
\text { ICER (\$) }\end{array}$ \\
\hline $\begin{array}{l}\text { Nitisinone } \\
\text { (Orfadin) }\end{array}$ & Hereditary tyrosinemia type 1 & Yes & 2002 & 28.2 & $8,075,081$ & 286,046 \\
\hline $\begin{array}{l}\text { Ivacaftor } \\
\text { (Kalydeco) }\end{array}$ & Cystic fibrosis & Yes & 2012 & 7.7 & $2,688,584$ & 347,362 \\
\hline $\begin{array}{l}\text { Deferasirox } \\
\text { (Exjade) }\end{array}$ & Transfusional hemosiderosis & Yes & 2005 & 4.2 & 181,595 & 43,271 \\
\hline $\begin{array}{l}\text { Imatinib } \\
\text { mesylate } \\
\text { (Gleevec) }\end{array}$ & Chronic myeloid leukemia & No & 2001 & 4.1 & 163,569 & 39,798 \\
\hline $\begin{array}{l}\text { Alglucosidase } \\
\text { alfa (Myozyme) }\end{array}$ & Pompe disease & Yes & 2006 & 3.2 & $9,485,238$ & $3,011,187$ \\
\hline $\begin{array}{l}\text { Ivacaftor; } \\
\text { lumacaftor } \\
\text { (Orkambi) }\end{array}$ & Cystic fibrosis & Yes & 2015 & 2.4 & $2,753,987$ & $1,138,011$ \\
\hline $\begin{array}{l}\text { Etanercept } \\
\text { (Enbrel) }\end{array}$ & Psoriatic arthritis & No & 2002 & 2.3 & 70,160 & 30,372 \\
\hline $\begin{array}{l}\text { Dinutuximab } \\
\text { (Unituxin) }\end{array}$ & Pediatric neuroblastoma & Yes & 2015 & 2.2 & 220,250 & 99,436 \\
\hline $\begin{array}{l}\text { Mepolizumab } \\
\text { (Nucala) }\end{array}$ & Severe eosinophilic asthma & No & 2015 & 1.5 & 625,753 & 408,989 \\
\hline $\begin{array}{l}\text { Ibrutinib } \\
\text { (Imbruvica) }\end{array}$ & Chronic lymphocytic leukemia & Yes & 2013 & 1.5 & 175,538 & 117,811 \\
\hline $\begin{array}{l}\text { Nivolumab } \\
\text { (Opdivo) }\end{array}$ & Renal cell carcinoma & No & 2014 & 1.5 & 246,665 & 168,949 \\
\hline $\begin{array}{l}\text { Pertuzumab } \\
\text { (Perjeta) }\end{array}$ & $\begin{array}{l}\text { Human epidermal growth factor } \\
\text { receptor 2-positive advanced breast } \\
\text { cancer }\end{array}$ & No & 2012 & 1.2 & 987,893 & 834,828 \\
\hline $\begin{array}{l}\text { Certolizumab } \\
\text { pegol (Cimzia) }\end{array}$ & Psoriatic arthritis & No & 2013 & 1.2 & 30,729 & 26,023 \\
\hline $\begin{array}{l}\text { Dapagliflozin } \\
\text { (Farxiga) }\end{array}$ & Type 2 diabetes mellitus & No & 2014 & 1.0 & -8011 & Dominant \\
\hline $\begin{array}{l}\text { Parathyroid } \\
\text { hormone } \\
\text { (Natpara) }\end{array}$ & Hypoparathyroidism & Yes & 2015 & 0.9 & 758,103 & 824,025 \\
\hline
\end{tabular}




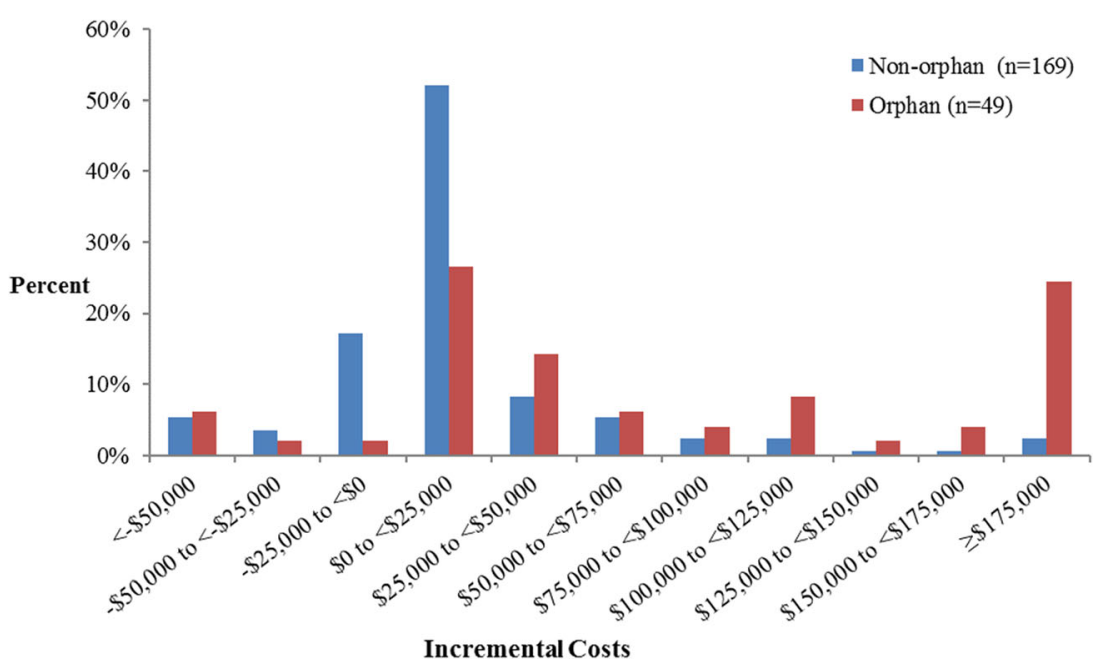

Figure 2 Distribution of incremental costs across orphan and non-orphan drugs. Source: Authors' analysis.

$10,000$ patients $),{ }^{20}$ regardless of the drug's cost-effectiveness ratio. Health technology assessment agencies in other countries also employ modified or separate processes to assess orphan drugs. $^{21,22}$ For example, the National Institute for Health and Clinical Excellence (NICE) in the UK adjusts its assessment criteria for Highly Specialized Technologies
(HSTs), which it defines as interventions indicated for diseases with a prevalence less than two per 100,000. Among other things, NICE's adjusted assessment criteria includes a costeffectiveness threshold that is roughly three to five times higher (less stringent) than the threshold for non-HST interventions ( $£ 100,000$ vs. $£ 20,000-30,000$ per QALY gained),

Table 3 Fifteen drugs with the largest additional costs over preexisting care

\begin{tabular}{|c|c|c|c|c|c|c|}
\hline $\begin{array}{l}\text { Chemical name } \\
\text { (brand name) }\end{array}$ & Indication & $\begin{array}{l}\text { Orphan } \\
\text { designation? }\end{array}$ & $\begin{array}{l}\text { Year of } \\
\text { FDA } \\
\text { approval }\end{array}$ & $\begin{array}{l}\text { Average } \\
\text { incremental } \\
\text { QALY gain }\end{array}$ & $\begin{array}{l}\text { Average incremental } \\
\text { cost over the time } \\
\text { period used in the } \\
\text { reviewed cost-utility } \\
\text { study }(\$)\end{array}$ & $\begin{array}{l}\text { Aggregate } \\
\text { ICER (\$) }\end{array}$ \\
\hline $\begin{array}{l}\text { Alglucosidase } \\
\text { alfa (Myozyme) }\end{array}$ & Pompe disease & Yes & 2006 & 3.2 & $9,485,238$ & $3,011,187$ \\
\hline $\begin{array}{l}\text { Nitisinone } \\
\text { (Orfadin) }\end{array}$ & Hereditary tyrosinemia type 1 & Yes & 2002 & 28.2 & $8,075,081$ & 286,046 \\
\hline $\begin{array}{l}\text { Agalsidase beta } \\
\text { (Fabrazyme) }\end{array}$ & Fabry disease & Yes & 2003 & 0.7 & $3,948,801$ & $5,641,144$ \\
\hline $\begin{array}{l}\text { Ivacaftor; } \\
\text { lumacaftor } \\
\text { (Orkambi) }\end{array}$ & Cystic fibrosis & Yes & 2015 & 2.4 & $2,753,987$ & $1,138,011$ \\
\hline $\begin{array}{l}\text { Ivacaftor } \\
\text { (Kalydeco) }\end{array}$ & Cystic fibrosis & Yes & 2012 & 7.7 & $2,688,584$ & 347,362 \\
\hline $\begin{array}{l}\text { Pertuzumab } \\
\text { (Perjeta) }\end{array}$ & $\begin{array}{l}\text { Human epidermal growth factor } \\
\text { receptor 2-positive advanced } \\
\text { breast cancer }\end{array}$ & No & 2012 & 1.2 & 987,893 & 834,828 \\
\hline $\begin{array}{l}\text { Parathyroid } \\
\text { hormone } \\
\text { (Natpara) }\end{array}$ & $\begin{array}{l}\text { Hypocalcemia in patients with } \\
\text { hypoparathyroidism }\end{array}$ & Yes & 2015 & 0.9 & 758,103 & 824,025 \\
\hline $\begin{array}{l}\text { Mepolizumab } \\
\text { (Nucala) }\end{array}$ & Severe eosinophilic asthma & No & 2015 & 1.5 & 625,753 & 408,989 \\
\hline $\begin{array}{l}\text { Daratumumab } \\
\text { (Darzalex) }\end{array}$ & Multiple myeloma & Yes & 2015 & 0.9 & 337,274 & 368,002 \\
\hline $\begin{array}{l}\text { Carfilzomib } \\
\text { (Kyprolis) }\end{array}$ & Multiple myeloma & Yes & 2012 & 0.6 & 307,633 & 476,950 \\
\hline $\begin{array}{l}\text { Nivolumab } \\
\text { (Opdivo) }\end{array}$ & $\begin{array}{l}\text { Renal cell carcinoma (second- } \\
\text { line therapy) }\end{array}$ & No & 2015 & 1.5 & 246,665 & 168,949 \\
\hline $\begin{array}{l}\text { Riociguat } \\
\text { (Adempas) }\end{array}$ & Pulmonary arterial hypertension & Yes & 2013 & -0.3 & 223,785 & Dominated \\
\hline $\begin{array}{l}\text { Palbociclib } \\
\text { (Ibrance) }\end{array}$ & $\begin{array}{l}\text { Estrogen receptor (ER)-positive, } \\
\text { human epidermal growth factor } \\
\text { receptor 2-negative advanced } \\
\text { breast cancer }\end{array}$ & No & 2015 & 0.5 & 221,628 & 460,526 \\
\hline $\begin{array}{l}\text { Dinutuximab } \\
\text { (Unituxin) }\end{array}$ & Pediatric neuroblastoma & Yes & 2015 & 2.2 & 220,250 & 99,436 \\
\hline $\begin{array}{l}\text { Deferasirox } \\
\text { (Exjade) }\end{array}$ & Transfusional hemosiderosis & Yes & 2005 & 4.2 & 181,595 & 43,271 \\
\hline
\end{tabular}


and a QALY-weighting scheme, which places more value on interventions that gain more than 10 QALYs. ${ }^{23}$ In another example, the Ontario Public Drug Programs in Canada has a separate assessment process that does not include a costeffectiveness criterion for drugs indicated for rare diseases. ${ }^{24}$ This process includes a review of the natural history of the disease, modeling of potential treatment effectiveness, and an evaluation of cost and budget impact.

Observers have debated whether orphan drugs should be valued differently than non-orphan drugs. Some observers point out that a potential consequence of greater leniency for orphan drugs is lower overall population health. ${ }^{25}$ Put another way, paying for less cost-effective orphan drugs takes resources away from treatments for unidentified patients suffering from more common diseases by denying them care they would have otherwise received. It is unclear, however, whether aggregate maximization of population health should be the primary goal of the health care system. Others argue that a health care system should prioritize treatments for severe, rare disorders, even if doing so reduces overall population health. ${ }^{26}$

\section{LIMITATIONS}

This study has a number of limitations. First, because of the lag between drug approval and publication of cost-utility analyses, we did not include drugs approved after 2015. ${ }^{27}$ Advances in precision medicine since 2015 may lead to the introduction of orphan products that differ systematically from those included in the present analysis. For example, novel gene therapies are likely to be more costly than existing drugs but may nonetheless be favorably cost-effective. ${ }^{28}$ Second, because estimates of incremental QALYs and incremental costs were not available for all drugs approved from 1999 through 2015, our findings may not generalize to all products approved during that time frame. Third, the included cost-utility analyses varied in terms of their country setting, methodology, perspective, and other factors. We mitigate bias by including only studies that were not funded by product manufacturers. Further, we found that characteristics on the included studies were similar (Appendix Table 2). Fourth, comparator therapies for a particular drug occasionally varied across studies. In these cases, to be conservative, we selected the most effective alternative available at the time of the drug's introduction. Fifth, while we converted all cost estimates to US dollars, we could not adjust for a variety of factors giving rise to different costs across countries such as differences in drug prices. Similarly, while we inflated incremental cost data to 2018 US dollars, we could not fully account for actual changes in costs over time. Finally, research has shown that the FDA typically imposes a less stringent evidence standard on orphan drugs than it imposes on non-orphan drugs (for example, approving orphan drugs despite the evidence base lacking randomized trials or consisting of studies with smaller sample sizes); the less complete evidence base may in turn affect the quality of the orphan drug costeffectiveness studies. ${ }^{29,} 30$

\section{Looking Forward}

The introduction of large numbers of orphan drugs seems set to continue. First, incentives provided by the Orphan Drug Act (including seven years of market exclusivity, tax credits, and the waiving of regulatory submission user fees) continue to provide a powerful inducement for orphan drug development. ${ }^{31}$ Second, there are no treatments for the vast majority of the estimated 7000 rare diseases that affect 25 million Americans. ${ }^{32}$ Third, orphan drugs can be highly profitable, with worldwide orphan drug sales expected to account for one-fifth of all prescription drug sales, or $\$ 242$ billion, in 2024. Fourth, advancements in molecular genetics have led to the development of increasingly targeted medicines. For instance, whereas drug developers previously targeted cancers based on the organ involved, they now target a subset of patients with a specific genetic mutation (e.g., lung cancer patients with mutation of the KRAS gene), thus leading to the development of more drugs with orphan status. ${ }^{32,33}$

\section{The Challenge Facing Health Care Payers}

The trend towards the availability of more orphan drugs is a positive development for patients, their families, and society at large. Yet, this trend is putting pressure on health care budgets and raises questions about whether the prices of such drugs are appropriate.

While historically health care payers could accommodate the few highly expensive orphan drugs without resorting to utilization management tools, this is beginning to change. As noted above, spending on orphan drugs has increased substantially, more than doubling as a percentage of total prescription drug spending from 1997 to $2017 .{ }^{6}$ Recent research has shown that while orphan drugs tend to be covered more generously than non-orphan drugs, they are still subject to coverage restrictions (such as patient subgroup restrictions or step therapy requirements) roughly $25 \%$ of the time. ${ }^{34}$ Another study has found that commercial health plans and Medicare often include orphan drugs in the highest copay tiers of their formularies. $^{35}$

Faced with higher prices and an increasing number of orphan drugs, health plans must find ways to provide patients appropriate access to orphan drugs while controlling drug costs. Research has shown that US commercial health plans limit orphan drug coverage to patient subgroups roughly $14 \%$ of the time. ${ }^{36}$

Another approach is to tie payment for drugs to positive health outcomes for patients, rather than to the volume of products used. ${ }^{37}$ However, implementing such agreements is limited by measurement challenges, high implementation costs, and data infrastructure requirements. ${ }^{38}$ The impact of such outcomes-based agreements to date has been unclear. ${ }^{39}$

Orphan products with a high upfront cost but health benefits that accrue over an extended time period (such as cell and gene therapies) are ill-suited to existing payment models that require payment at the time of treatment. ${ }^{40}$ Models that instead 
allow the health care payer to pay only a portion of the treatment cost initially and spread remaining payments over the period during which the patient experiences treatment benefits have been proposed as solutions. A payment-overtime model could be combined with an outcomes-based agreement, with future payments contingent on treatment benefit. However, implementation of payment-over-time models is complicated by the fact that patients can switch health plans. ${ }^{41}$

\section{CONCLUSION}

Our study indicates that orphan drugs tend to offer larger health gains than non-orphan drugs, but also that they tend to have substantially higher incremental costs, and as a result, orphan drugs are typically less cost-effective than non-orphan drugs.

Corresponding Author: James D. Chambers, PhD; Center for the Evaluation of Value and Risk in Health, Institute for Clinical Research and Health Policy Studies, Tufts Medical Center, Boston, MA, USA (e-mail: jchambers@tuftsmedicalcenter.org).

\section{Compliance with Ethical Standards:}

Conflict of Interest: The authors did not receive any external funding for this research.

\section{REFERENCES}

1. Sarpatwari A, Beall RF, Abdurrob A, He M, Kesselheim AS. Evaluating The Impact Of The Orphan Drug Act's Seven-Year Market Exclusivity Period. Health Aff (Millwood). 2018;37(5):732-737.

2. Authors analysis of the FDA Novel Drugs Summary Reports. New Drugs at FDA: CDER's New Molecular Entities and New Therapeutic Biological Products. From 2015 through 2018, 48\% (82/172) of approved drugs have been orphan drugs. Available https://www.fda.gov/drugs/development-approval-process-drugs/new-drugs-fda-cders-new-molecular-entities-and-new-therapeutic-biological-products.

3. "FDA Approves First Therapy for Rare Joint Tumor." U.S. Food and Drug Administration, FDA, 2 Aug. 2019, www.fda.gov/news-events/pressannouncements/fda-approves-first-therapy-rare-joint-tumor.

4. "FDA Approves First Therapy for the Treatment of Adult Patients with a Rare Blood Clotting Disorder." U.S. Food and Drug Administration, FDA, 6 Feb. 2019, www.fda.gov/news-events/press-announcements/fda-approves-first-therapy-treatment-adult-patients-rare-blood-clottingdisorder.

5. Handfield R, Feldstein J. Insurance companies' perspectives on the orphan drug pipeline. Am Health Drug Benefits. 2013;6(9):589-598.

6. EvaluatePharma ${ }^{\circledR}$ Orphan Drug Report 2019 6th Edition - May 2019 Available https://www.evaluate.com/sites/default/files/media/download-files/EvaluatePharma_Orphan_Drug_Report_2019.pdf.

7. IQVIA Institute for Human Data Science. Orphan Drugs in the United States: Growth Trends in Rare Disease Treatments. October 2018 https://www.iqvia.com/-/media/iqvia/pdfs/institute-reports/orphandrugs-in-the-united-states-growth-trends-in-rare-disease-treatments. pdf?_=1544648528329. Accessed March 12, 2019.

8. Chua KP, Conti RM. Out-of-pocket Spending on Orphan Drug Prescriptions Among Commercially Insured Adults in 2014. J Gen Intern Med. 2019;34(3):338-340.

9. Chambers JD, Thorat T, Pyo J, Chenoweth M, Neumann PJ. Despite high costs, specialty drugs may offer value for money comparable to that of traditional drugs. Health Aff (Millwood). 2014;33(10):1751-60.
10. Chambers JD, Thorat T, Wilkinson CL, Neumann PJ. Drugs cleared through the FDA's expedited review offer greater gains than drugs approved by conventional process. Health Aff (Millwood). 2017;36(8): 1408-1415.

11. Williams A. QALYS and ethics: a health economist's perspective. Soc Sci Med. 1996;43(12): 1795-804.

12. The Food and Drug Administration. Drugs@FDA: FDA Approved Drug Products. Available https://www.accessdata.fda.gov/scripts/cder/daf/.

13. Garattini L, Koleva D, Casadei G. Modeling in pharmacoeconomic studies: funding sources and outcomes. Int J Technol Assess HealthCare. 2010;26(3):330-3.

14. Bell CM, Urbach DR, Ray JG, Bayoumi A, Rosen AB, Greenberg D, et al. Bias in published cost effectiveness studies: systematic review. BMJ. 2006;332(7543):699-703.

15. Tang DH, Armstrong EP, Lee JK. Cost-utility analysis of biologic treatments for moderate-to-severe Crohn's disease. Pharmacotherapy. 2012;32(6):515-26.

16. U.S. Food \& Drug Administration. Search Orphan Drug Designations and Approvals. Available https://www.accessdata.fda.gov/scripts/ opdlisting/oopd/index.cfm.

17. Board of Governors of the Federal Reserve System. Foreign exchange rates-H.10 [Internet]. Washington (DC): The Board; [last updated 2019 May 28 ; cited 2019 May 30]. Available from: http://www.federalreserve. gov/releases/H10/Hist/default.htm.

18. Bureau of Labor Statistics. Consumer Price Index [Internet]. Washington (DC): Department of Labor; [cited 2019 May 30]. Available from: http:// www.bls.gov/cpi/.

19. When calculating median values of cost-effectiveness, we excluded estimates for which the drug was both less effective and less costly than the comparator $(n=27)$. We did this because such values are interpreted differently than cost-effectiveness estimates for which the drug is more effect and more costly than the comparator.

20. Institute for Clinical and Economic Review. Assessing the Effectiveness and Value of Drugs for Rare Conditions. May 2017 Available https://icerreview.org/material/final-ultra-rare-adaptations/.

21. Tordrup DTV, Kanavos P. Orphan drug considerations in Health Technology Assessment in eight European countries. Rare Dis Orphan Drugs. 2014;1 (3):83-95.

22. Ollendorf DA, Chapman RH, Pearson SD. Evaluating and valuing drugs for rare conditions: no easy answers. Value Health. 2018;21 (15):547552.

23. National Institute for Health and Clinical Excellence. Interim Process and Methods of the Highly Specialised Technologies Programme Updated to reflect 2017 changes. Available https://www.nice.org.uk/Media/Default/ About/what-we-do/NICE-guidance/NICE-highly-specialised-technologies-guidance/HST-interim-methods-process-guide-may-17.pdf. Accessed February 3rd, 2020.

24. Winquist E, Coyle D, Clarke JT, Evans GA, Seager C, Chan W, Martin J. Application of a policy framework for the public funding of drugs for rare diseases. J Gen Intern Med. 2014 Aug;29 Suppl 3:S774-9.

25. McCabe C, Claxton K, Tsuchiya A. Orphan drugs and the NHS. Br Med J. 2005;331:1016-19.

26. Drummond MF, Wilson DA, Kanovos P, Ubel P, Rovira J. Assessing the economic challenges posed by orphan drugs. Int $\mathrm{J}$ Technol Assess Health Care. 2007;23 (1):36-42.

27. Chambers JD, Thorat T, Pyo J, Neumann PJ. The lag from FDA approval to published cost-utility evidence. Expert Rev Pharmacoecon Outcomes Res. 2015;15 (3):399-402.

28. Cohen JT, Chambers JD, Silver MC, Lin PJ, Neumann PJ. Putting The Costs And Benefits Of New Gene Therapies Into Perspective. Health Affairs Blog. September 4, 2019. Available https://www.healthaffairs. org/do/10.1377/hblog20190827.553404/full/. Accessed 3 feb 2020.

29. Kesselheim AS, Myers JA, Avorn J. Characteristics of clinical trials to support approval of orphan vs nonorphan drugs for cancer. JAMA. 2011 Jun 8;305(22):2320-2326.

30. Mitsumoto J, Dorsey ER, Beck CA, Kieburtz K, Griggs RC. Pivotal studies of orphan drugs approved for neurological diseases. Ann Neurol. 2009;66 (2): 184-90.

31. Thomas S, Caplan A. The Orphan Drug Act Revisited. JAMA. 2019;321 (9):833-834 .

32. National Center for Advancing Translational Sciences. Genetic and Rare Diseases Information Center. FAQs About Rare Diseases. Available https://rarediseases.info.nih.gov/diseases/pages/31/faqs-about-rarediseases. 
33. American Cancer Society. Targeted Therapy Drugs for Non-Small Cell Lung Cancer. Available https://www.cancer.org/cancer/non-small-celllung-cancer/treating/targeted-therapies.html

34. Chambers JD, Kim DD, Pope EF, Graff JS, Wilkinson CL, Neumann PJ. Specialty drug coverage varies across US commercial health plans. Health Aff (Millwood). 2018; 37 (17): 1041-1047.

35. Cohen JP, Awatin JW. Patient access to orphan drugs. Expert Opinion on Orphan Drugs. 20175 (12):923-932.

36. Chambers JD, Panzer AD, Kim DD, Margaretos NM, Neumann PJ. Variation in US private health plans' coverage of orphan drugs. Am J Manag Care. 2019;25 (10):508-512.

37. Carlson JJ, Sullivan SD, Garrison LP, Neumann PJ, Veenstra DL. Linking payment to health outcomes: a taxonomy and examination of performance-based reimbursement schemes between healthcare payers and manufacturers. Health Policy. 2010;96 (3):179-90.
38. Neumann PJ, Chambers JD, Simon F, Meckley LM. Risk-sharing arrangements that link payment for drugs to health outcomes are proving hard to implement. Health Aff (Millwood). 2011;30 (12):2329-37.

39. Seeley E, Kesselheim AS. Outcomes-Based Pharmaceutical Contracts: An Answer to High U.S. Drug Spending? September 27, 2017. Available https://www.commonwealthfund.org/publications/issue-briefs/2017/ sep/outcomes-based-pharmaceutical-contracts-answer-high-us-drug.

40. Ali F, Slocomb T, Werver M. Curative regenerative medicines: preparing health care systems for the coming wave. In Vivo. 2016;34 (10):26-33.

41. Salzman R, Cook F, Hunt T, Malech HL, Reilly P, Foss-Campbell B, Barrett D. Addressing the Value of Gene Therapy and Enhancing Patient Access to Transformative Treatments. Mol Ther. 2018;26 (12):2717-2726.

Publisher's Note Springer Nature remains neutral with regard to jurisdictional claims in published maps and institutional affiliations. 